\title{
Measurement of Different Heavy Metals Concentration in Roadside Dust in the Vicinity of Gujrat, Pakistan
}

\author{
Nusrat Bashir ${ }^{1}$, Mujahid Farid ${ }^{1}$, Rashid Saeed ${ }^{1}$, Hafiz Muhammad Tauqeer ${ }^{1}$, Shafaqat Ali ${ }^{2}$, \\ Muhammad Rizwan ${ }^{2}$, Ayesha Siddiqua ${ }^{1}$, Rasham Sallah-Ud-Din ${ }^{1}$ \\ ${ }^{1}$ Department of Environmental Sciences, University of Gujrat, Hafiz Hayat Campus, Gujrat, Pakistan \\ ${ }^{2}$ Department of Environmental Sciences and Engineering, Government College University, Faisalabad, Pakistan
}

Email address:

mujahid726@yahoo.com (M. Farid)

\section{To cite this article:}

Nusrat Bashir, Mujahid Farid, Rashid Saeed, Hafiz Muhammad Tauqeer, Shafaqat Ali, Muhammad Rizwan, Ayesha Siddiqua, Rasham Sallah-Ud-Din. Measurement of Different Heavy Metals Concentration in Roadside Dust in the Vicinity of Gujrat, Pakistan. Science Journal of Chemistry. Vol. 5, No. 4, 2017, pp. 51-57. doi: 10.11648/j.sjc.20170504.12

Received: December 18, 2016; Accepted: March 7, 2017; Published: August 29, 2017

\begin{abstract}
Due to rapid urbanization and industrialization in many countries of the world, heavy metals are continuously emitted into the terrestrial environment and posing great threat to human health. The present study was conducted to measure the concentration of six heavy metals, chromium $(\mathrm{Cr})$, nickel $(\mathrm{Ni})$, cobalt $(\mathrm{Co})$, zinc $(\mathrm{Zn})$, cadmium $(\mathrm{Cd})$ and lead $(\mathrm{Pb})$ in roadside dust of five major roads in Gujrat city. The dust samples were collected from five different locations in the vicinity of Gujrat. The results showed that the average concentrations of $\mathrm{Cr}, \mathrm{Ni}, \mathrm{Co}, \mathrm{Zn}, \mathrm{Cd}$, and $\mathrm{Pb}$ in the dust samples were higher than their permissible limits. The concentrations of $\mathrm{Cu}, \mathrm{Zn}, \mathrm{Cd}$ and $\mathrm{Pb}$ were much higher than those in the background value of Gujrat soil. Results clearly concluded that the heavy traffic and transportation is the major responsible source of these heavy metals in the road dust of Gujrat city along with the transportation of sewage sludge, surface runoff from agricultural land and discharge of sewage water from drains.
\end{abstract}

Keywords: Industrialization, Heavy Metal, Traffic, Chromium, Lead, Sludge

\section{Introduction}

Pollution is the most severe problem in developing countries now a day $[36,16]$. Continous increasing population leads the pollution by using transport and industrialization. In urban areas, traffic is more congested as compared to rural areas [30]. Roads are considered as the second largest non-point source of pollution in all media of environment $[44,15]$. Developed countries could combat or minimize traffic pollution impacts by using different advanced technologies and recourses because they have substantial economic parameters as compared to developing countries [18]. Anthropogenic activities, paints, petrol, aerosols are the major sources of traffic pollution [3].

In Pakistan about $38.6 \%$ is urban population [42]. Due to rapid urbanization the roads are loaded with high burden of traffic which cause more pollution in urban areas. Due to the deficiency of resources, poverty, lake of awareness and government's perfunctory; Pakistan is struggling to control traffic pollution.

The major concern of time is the emission of heavy metals from transportation and other means. These heavy metals has ability to circulate in all media of environment by biomagnifications and bioaccumulation. These not just pollute the soil but also accumulate in food plants [32, 19, 24] and intake by human and animals during food consumption and cause health related problems $[35,1]$. Traffic pollution has emerged as a serious issue due to potential hazard on human health and nearby environment. Road dust could easily be inhaled, ingested or absorbed by human beings due to its small particle size $[8,9]$. These persistent heavy metals cause potential threat to human health and safety along with environment. In small concentrations, some heavy metals are necessary for plants and human health but in excessive amount these are toxic $[15,5,2]$. People living or working near roadways, are more vulnerable to health related problems with respect to the people living in remote areas. The severe health problems which they face are asthma, cardiac diseases, lungs disorder (i.e. asthma, bronchitis, 
Chronic obstructive pulmonary disease (COPD), lung cancer, (Pneumonia) premature deaths and brain disorder. Heavy metals incorporate in bio-geochemical cycle and disturbed the natural environment [40].

Recent studies reported that natural weathering of building material, industrial emissions, tire abrasion, mining processes, fuel burning at homes, metallurgical processes, brick kilns and heating systems inside the vehicles are also responsible for producing different heavy metals as a byproduct [43] but burning of gasoline produce more percentage of heavy metals.

Climatic conditions, traffic frequency and density, urbanization, temperature profile and topography of that area are the effective factors for the distribution and contamination of road dust [22].

Keeping In view the above described scenario the present study was planned to estimate the concentration of six selected heavy metals at five different locations of Gujrat City, Pakistan.

\section{Material and Methods}

\subsection{Study Area}

The geographical location of Gujrat city is " $32^{0} 40$ ' $\mathrm{N}$ latitude and " $74^{0} 4$ ' $E$ " longitude. The location of study area is shown in figure 1.

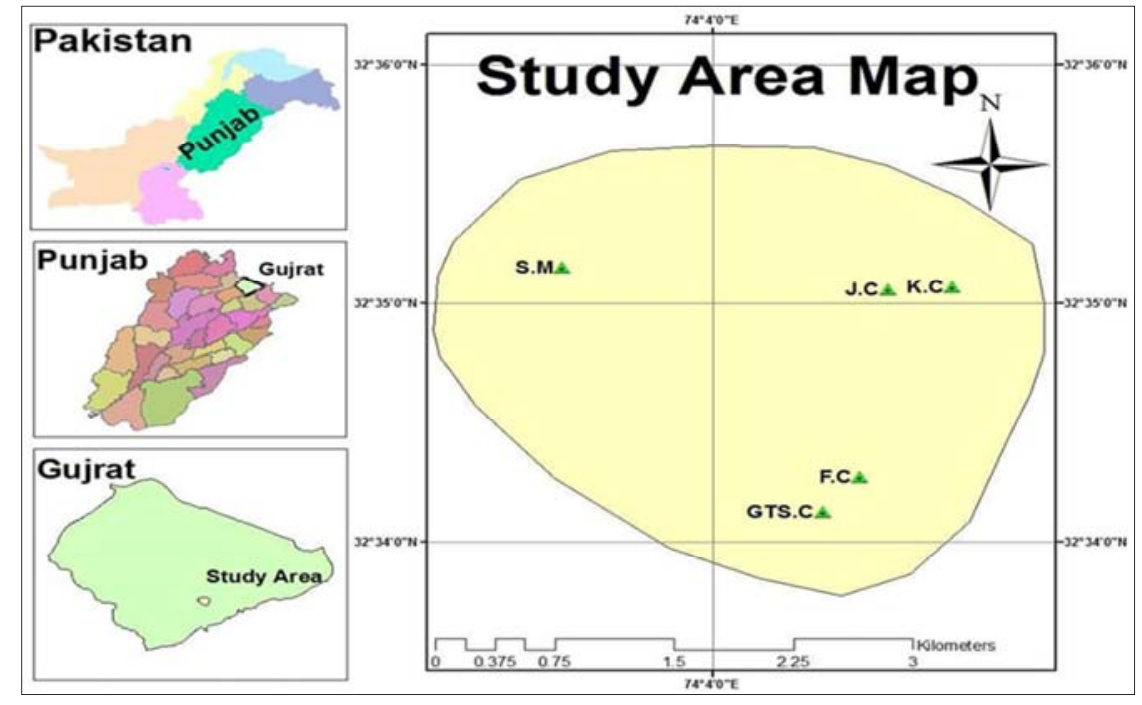

Figure 1. Map of study area.

Soil samples were collected from five selected sites of Gujrat city. Samples were collected in dry season because rainfall may keep wet the soil present on roads and green belts. The samples were collected in three replicates from each location. Soil samples at $0-10 \mathrm{~cm}$ depth of surface soil were collected in polythene bags with the approximately weight of 500 grams. Samples were collected during peak hours of traffic i.e. in between 7:30am-9:30am in the morning and $2: 00 \mathrm{Pm}-5: 30 \mathrm{pm}$ in the evening. During sample collection, efforts were made to avoid other contamination, organic waste, debris material, effluents, and industrial wastes and manure objects that might disguise the outcome of motor vehicle discharge. All cores taken for a given sample were collected in a clean bucket and mixed thoroughly. As crushing is easier at right moisture level, the soil was passed through 2- $3 \mathrm{~mm}$ sieve and air dried. Samples were preserved at room temperature $\left(25^{\circ} \mathrm{C}\right)$ for further analysis of heavy metal concentration.

\subsection{DTPA Preparation}

$1.97 \mathrm{~g}$ of DTPA (Diethylenetriamine Penta acetic Acid), $1.1 \mathrm{~g}$ of anhydrous $\mathrm{CaCl}_{2}$ and $14.92 \mathrm{~g}$ of TEA (tri-ethanol amine) were dissolved in approximately $800 \mathrm{ml}$ of distilled water. DTPA requires a sufficient time on hate plate, along with magnetic stirrer to dissolve, and then prepare volume. The $\mathrm{pH}$ was adjusted at 7.3 with $1: 1 \mathrm{HCl}$ or $1: 1 \mathrm{NH}_{4} \mathrm{OH}$ while stirring [29].

\subsection{Method for Soil Analysis}

$25 \mathrm{~g}$ soil sample was taken and $50 \mathrm{ml}$ of DTPA solution added to it. Then it was shaken continuously for 2 hours on horizontal shaker and then filtered to a flask. A blank solution (containing all reagents except soil) was run with samples as blank. Read each element concentration on concentration mode by Atomic Absorption Spectrophotometer (novAA 350, based in Jena, Germany) (At least 5 standards were prepared for each element with a range as following in the table 1. [15].

Table 1. Standards for heavy metals.

\begin{tabular}{lll}
\hline Serial No. & Heavy Metals & Parameters/ Standards \\
\hline 1 & Lead $(\mathrm{Pb})$ & $0.5,1.0,1.5,2.0,2.5 \mathrm{ppm}$ \\
2 & Cobalt $(\mathrm{Co})$ & $0.5,1.0,1.5,2.0,2.5 \mathrm{ppm}$ \\
3 & Chromium $(\mathrm{Cr})$ & $0.5,1.0,1.5,2.0,2.5 \mathrm{ppm}$ \\
4 & Cadmium $(\mathrm{Cd})$ & $0.5,1.0,1.5,2.0,2.5 \mathrm{ppm}$ \\
5 & Nickel $(\mathrm{Ni})$ & $0.5,1.0,1.5,2.0,2.5 \mathrm{ppm}$ \\
6 & Zinc $(\mathrm{Zn})$ & $0.5,1.0,1.5,2.0,2.5 \mathrm{ppm}$ \\
\hline
\end{tabular}




\subsection{Calculations Required}

Heavy Metal $(\mathrm{ppm})=$ AAS reading $\mathrm{x}$ dilution factor

\subsection{Statistical Analysis}

Different procedures of statistical analysis were used to analyze data. All statistical analysis were done using SPSS (Statistical Package for Social Sciences).

\section{Results}

Concentration of different heavy metals was measured at five selected locations in the vicinity of Gujrat city. All samples were in positive value for heavy metal contamination in traffic congested areas of Gujrat. At location (A) the concentration of $\mathrm{Pb}$ was higher as compared to other heavy metals such as $\mathrm{Pb}>\mathrm{Zn}>\mathrm{Cd}>\mathrm{Cr}>\mathrm{Co}>\mathrm{Ni}$ while Similar trend was found at location (B) where $\mathrm{Ni}$ concentration was slightly equal to the concentration of $\mathrm{Co}$ while $\mathrm{Zn}$ concentration was not significantly different from $\mathrm{Pb}$.
The location $(\mathrm{C})$ has maximum value of $\mathrm{Pb}$ followed by $\mathrm{Zn}, \mathrm{Cd}, \mathrm{Cr}$, Co and Ni respectively. Cobalt found in lesser quantity as compared to other heavy metals at location (D). The sequence can be written as $\mathrm{Co}<\mathrm{Ni}<\mathrm{Cd}<\mathrm{Zn}<\mathrm{Cr}<\mathrm{Pb}$. Quite similar trend found at location (E) but the concentration of $\mathrm{Cd}$ was lesser while $\mathrm{Zn}$ concentration was higher as compared to location (D) such as $\mathrm{Co}<\mathrm{Cd}<\mathrm{Ni}<\mathrm{Cr}<\mathrm{Zn}<\mathrm{Pb}$.

The comparison of single heavy metal concentration at all locations is given in Figure 3. Almost all samples were is positive value of selected heavy metals while $\mathrm{Pb}$ concentration was found higher at all locations and Kachari Chowk holds the maximum concentration of $\mathrm{Pb}$ while other locations were not significantly different from each other. Cobalt concentrations were found lesser at all locations and were not significantly different to each other. Zinc holds second highest concentration at all locations but not significantly different from each other except Kachari and GTS chowk. $\mathrm{Cr}$ and $\mathrm{Cd}$ were found almost in same range of concentrations at all locations. Ni concentration was lesser at Fawara chowk while found highest at Kachari chowk.
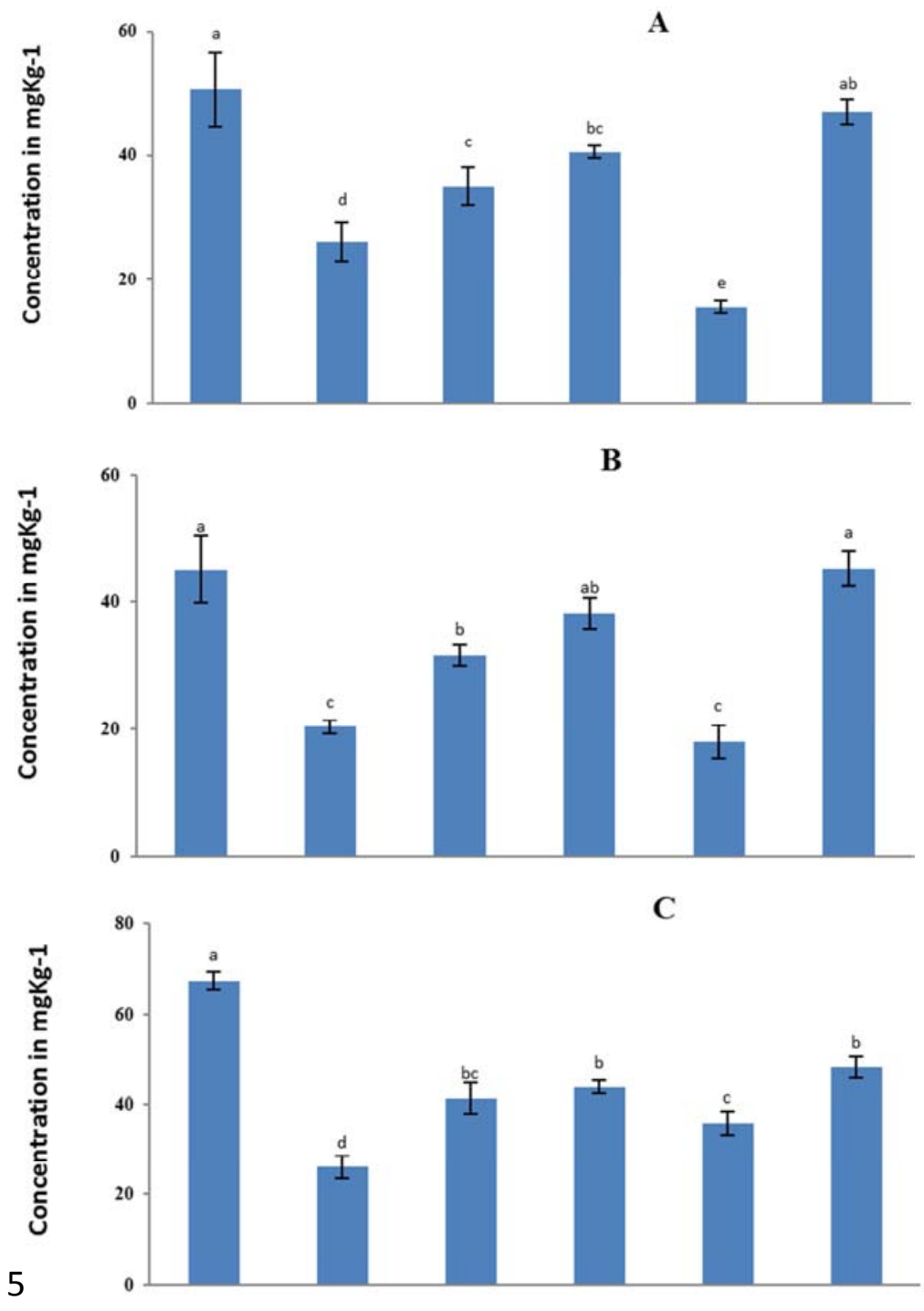

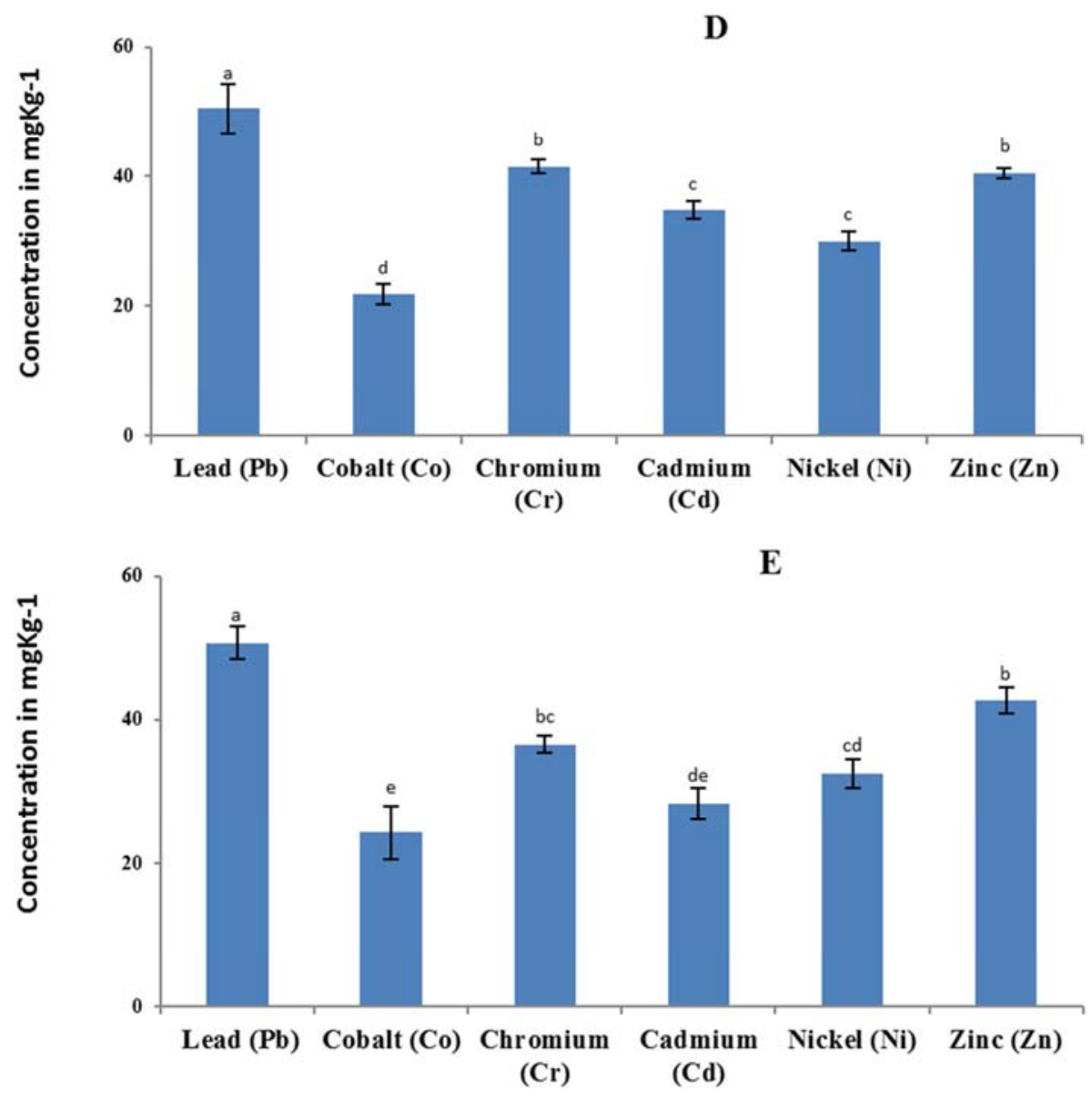

Figure 2. The concentration of lead (Pb), cobalt (Co), chromium (Cr), cadmium (Cd), nickel (Ni) and zinc (Zn) at Fawara Chowk (A), Jail Chowk (B), Katchari Chowk (C), GTS Chowk (D) and Service Morr Chowk (E). Values are means of three replicates $\pm S$. D. Different small letters on bars depicts that values are significantly different from each other at $p \leq 0.005$.

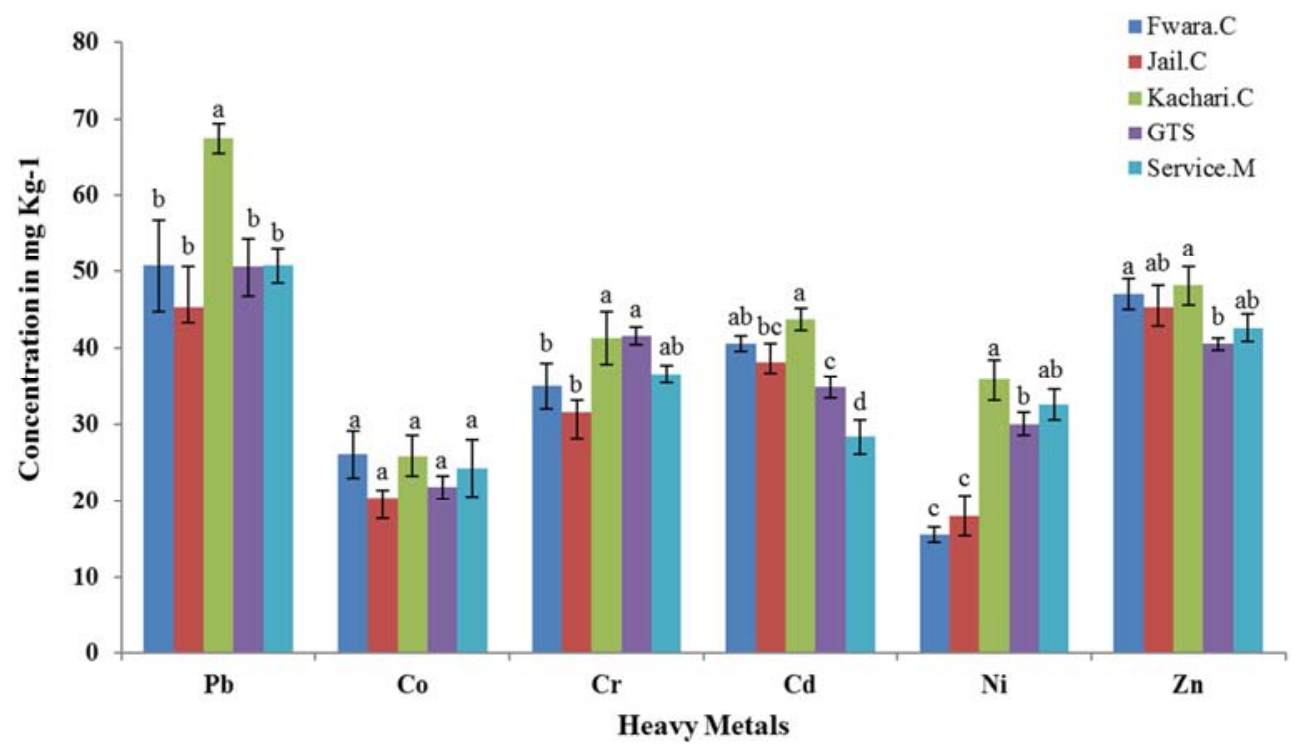

Figure 3. The concentration of lead (Pb), cobalt (Co), chromium (Cr), cadmium (Cd), nickel (Ni) and zinc (Zn) at Fawara Chowk, Jail Chowk, Katchari Chowk, GTS Chowk and Service Morr Chowk. Values are means of three replicates $\pm S$. D. Different small letters on bars depicts that values are significantly different from each other at $p \leq 0.005$.

\section{Discussion}

Assessment of heavy metals is becoming an important tool to determine the quality of traffic pollution at a specific point, both in rural and urban environments. The concentration of heavy metal is more in traffic congested areas. Traffic volume is increasing by public dependence more on their 
private transport. This dependence or leasing of private transport cause more transport, more fuel consumption and eventually more traffic pollution [38]. In developed countries there is proper legislation for monitoring and tuning of vehicles on regular basis. This constant increase in number of automobiles lead to more traffic load on roads and cause traffic jams due to which more pollutants released into the atmosphere. The seasonal changes affect the contamination of heavy metals in road dust such as, heavy metal concentration is more in normal to dry season, while in rainy season these spread/thresh away along with water and diluted $[33,25]$.

The current study involved the monitoring of different heavy metals, from road dust during the peak hours of traffic. The traffic volume changes along with school and office timings. i.e. from 7:30am to 9:30am in the morning and 2:30pm $-5: 30 \mathrm{pm}$ in the evening. Traffic stampede was found to be increasing gradually and a bit higher concentration of heavy metals was recorded. In current study the most elevated level of lead was at location L3 Kachari Chowk (Fig $2 \& 3$ ). Contamination level of $\mathrm{Pb}$ is at elevated levels in metropolitan areas [23] when large number of vehicles passed at the timing of rush hours [12]. The heavy metals emitted from automobiles exhausr dispersed in the atmosphere and then accumulated in the surrounding environment, plant, fruits (which kept by vendors in open air) $[21,37]$. Further these heavy metals taken up by human beings and biomagnified in food chain and food web [39, 31]. Approximately 3600 automobiles passing through this point which includes, rickshaws, motor bikes, cars, buses/mini buses, hiace/bolan etc. Lead also entered into the atmosphere by wind erosion, during sludge transportation and sludge extraction. A study was conducted by yang. (2011) that $\mathrm{Pb}$ contamination was due to over urbanization and industrialization but in current study this might be due to congested traffic pollution [45].

In current study the level of Co contamination was also least as compared to other selected heavy metals. General source are mining and industrial wastes, vehicle emissions, lead-acid batteries, fertilizers, paints, treated woods, plastics floating in rivers and drains [20,34]. Cobalt can accumulate to toxic levels in the liver, kidney, pancreas, and heart, as well as the skeleton and skeletal muscles [6]. Cobalt has been found to produce tumors in animals and is likely a human carcinogen as well. Occupational exposure to cobalt powder has been linked to vision, asthma and hearing problems [41].

The adjacent areas of Gujrat city are more congested in tannery industry such as Sialkot and Gujranwala. The waste water coming from these cities through drains and also transportation of the tannery trough the Gujrat city is the major source of $\mathrm{Cr}$ in roadside dust. Aydin et al. (2006) reported that elevated level of $\mathrm{Cr}$ was due to industrialization but in current study it might be due to tannery industry and its transportation by roads [14]. These are carcinogenic in nature and affects public health [27, 11].

Automobile emissions are the major source of $\mathrm{Cd}$ contamination [26]. Inhalation exposure of $\mathrm{Cd}$ can occur from road dust. Prolonged exposure to $\mathrm{Cd}$ can cause severe toxicity in humans. Mostly $\mathrm{Cd}$ affects the kidney and lungs of human beings [4].

According to Eisler (2007) nickel contamination mainly originates from industrial and traffic pollution [17]. According to Doung and Lee. (2011) atmospheric dispersion and frequently brake use were additional factors in nickel contamination [13]. Nickel moves along with food web by bio-accumulation and bio-magnification that cause several diseases such as skin allergy, lung and cardiovascular diseases [10, 25].

At L2 (jail chowk) number of hospitals and pharmacies are more as compared to other locations, so that's why zinc is released from hospital waste and pharmaceutical waste (Figure 3). Approximately 372 automobiles passing through this point per hour which includes cars, motor bikes, rickshaws, hiace and buses etc. Zn released in atmosphere and affects human health and also causes damages to environment [28].

\section{Conclusion}

The results of present study concluded that the concentration of selected heavy metals, $\mathrm{Pb}, \mathrm{Co}, \mathrm{Cr}, \mathrm{Cd}, \mathrm{Ni}$ and $\mathrm{Zn}$ were found in roadside dust of Gujrat City which clearly indicated that the heavy traffic and transportation is the major responsible source of these heavy metals along with other sources. There is need to develop and implement the proper legislation for the monitoring and maintaining of automobile vehicles and transportation of waste material.

\section{References}

[1] Adrees M, Ali S, Rizwan M, Ibrahim M, Abbas F, Farid M, Ziaur-Rehman M, Irshad MK, Bharwana SA (2015a) The effect of excess copper on growth and physiology of important food crops: A. review. Environmental Science and Pollution Research 22(11): 8148-8162. doi: 10.1007/s11356-015-4496-5.

[2] Adrees M, Ali S, Rizwan M, Zia-ur-Rehman M, Ibrahim M, Abbas F, Farid M, Qayyum MF, Irshad MK (2015b) Mechanisms of silicon-mediated alleviation of heavy metal toxicity in plants: A. review. Ecotoxicology and $\begin{array}{llll}\text { Environmental Safety 119: 186-197. doi: } & \end{array}$ 10.1016/j.ecoenv.2015.05.011.

[3] Akhter MS, Madany IM (1993) Heavy metals in street and house dust in Bahrain. Water, Air, and Soil Pollution 66(1), 111-119. doi: 10.1007/BF00477063.

[4] Al-Fatlawi SM, Al-Alwani M, (2012) Heavy metals pollution of roadside dust sample with different traffic volumes at Hilla city. The Iraqi Journal for Mechanical And Material Engineering 12(4): 660-672.

[5] Ali S, Bharwana SA, Rizwan M, Farid M, Kanwal S, Ali Q, Ibrahim M, Gill RA, Khan MD (2015) Fulvic acid mediates chromium $(\mathrm{Cr})$ tolerance in wheat (Triticumaestivum L.) through lowering of $\mathrm{Cr}$ uptake and improved antioxidant defense system. Environmental Science and Pollution Research 22(14): 10601-10609. doi: 10.1007/s11356-0154271-7. 
[6] Apostoli P, Catalani S, Zaghini A, Mariotti A, Poliani PL, Vielmi V, Semeraro F, Duse S, Porzionato A, Macchi V, Padovani A, Rizzetti MC, de Caro R. (2013) High doses of cobalt induce optic and auditory neuropathy. Experimental and Toxicologic Pathology 65(6): 719-727. doi: 10.1016/j.etp.2012.09.006.

[7] Benin AL, Sargent JD, Dalton M, Roda S. (1999) High concentrations of heavy metals in neighborhoods near ore smelters in northern Mexico. Environmental Health Perspectives 107(4): 279-284.

[8] Bharwana SA, Ali S, Farid M, Jamshaid M, Azeem M, Shakoor MB, Ahmad R, Hannan F. (2014) Noise and ambient air pollution monitoring and its effects on local community in Faisalabad, Pakistan. Academia Journal of Environmental Sciences 2(2): 15-28.

[9] Bharwana SA, Ali S, Farid M, Hannan F, Ahmad R, Tauqeer HM, Baloch IH, Iqbal M. (2015) Work related injuries in small scale metal press industries of Shahdra Town, Lahore, Pakistan. The Holistic Approach to Environment 5(1): 3-11.

[10] Chashschin VP, Artunina GP, Norseth T. (1994) Congenital defects, abortion and other health effects in nickel refinery workers. Science of The Total Environment 148(2): 287-291. doi: 10.1016/0048-9697(94)90405-7.

[11] Chervona Y, Arita A, Costa M. (2012) Carcinogenic metals and the epigenome: understanding the effect of nickel, arsenic, and chromium. Metallomics 4(7): 619-627. doi: $10.1039 / \mathrm{c} 2 \mathrm{mt} 20033 \mathrm{c}$.

[12] Cholak J, Schafer LJ, Yeager D. (1968) The air transport of lead compounds present in automobile exhaust gases. American Industrial Hygiene Association Journal 29(6): 562568. doi: $10.1080 / 00028896809343056$.

[13] Duong TTT, Lee BK. (2011) Determining contamination level of heavy metals in road dust from busy traffic areas with different characteristics. Journal of Environmental Management 92(3): 554-562. doi: 10.1016/j.jenvman.2010.09.010.

[14] Duzgoren-Aydin NS, Aydin A. (2006) Chemical and mineralogical heterogeneities of weathered igneous profiles: implications for landslide investigations. Natural Hazards and Earth System Science, 6(2): 315-322.

[15] Ehsan S, Ali S, Noureen S, Farid M, Shakoor MB, Aslam A, Bharwana SA, Tauqeer HM (2013) Comparative assessment of different heavy metals in urban soil and vegetables irrigated with sewage/industrial waste water. Ecoterra Journal of Environmental Research and Protection 35: 37-53.

[16] Ehsan S, Ali S, Noureen S, Mehmood K, Farid M, Ishaque W, Shakoor MB, Rizwan M. (2014) Citric acid assisted phytoremediation of Cd by Brassica napus L. Ecotoxicology and Environmental Safety. 106: 164-172.

[17] Eisler R. (2007) Eisler's encyclopedia of environmentally hazardous priority chemicals. Elsevier, Amsterdam, The Netherlands. 986p.

[18] Ezeala-Harrison F. (2015) Environmental Quality in economic development in low-income countries: Application of an EQT model using cross-country sample data. Journal of Sustainable Development 8(2): 122-133 doi: 10.5539/jsd.v8n2p122.

[19] Farid M, Ali S, Ishaque W, Shakoor MB, Niazi NK, Bibi I, Dawood M, Gill RA, Abbas F (2015) Exogenous application of thylenediamminetetraacetic acid enhanced phytoremediation of cadmium by Brassica napusL. International Journal of Environmental Science and Technology 12(12): 3981-3992. doi: 10.1007/s13762-015-0831-0.

[20] Gill HS, Grammatopoulos G, Adshead S, Tsialogiannis E, Tsiridis E. (2012) Molecular and immune toxicity of $\mathrm{CoCr}$ nanoparticles in MoM hip arthroplasty. Trends in Molecular Medicine 18(3): 145-155. doi:

10.1016/j.molmed.2011.12.002.

[21] Habiba U, Ali S, Farid M, Shakoor MB, Rizwan M, Ibrahim M, Abbasi GH, Hayat T, Ali B. (2015) EDTA enhanced plant growth, antioxidant defense system, and phytoextraction of copper by Brassica napus L. Environmental Science and Pollution Research 22(2): 1534-1544. doi: 10.1007/s11356014-3431-5.

[22] Hidalgo J, Masson V, Pigeon G. (2008) Urban-breeze circulation during the CAPITOUL experiment: numerical simulations. Meteorology and Atmospheric Physics 102(3-4): 243-262. doi: 10.1007/s00703-008-0345-0.

[23] Kabadayi F, Cesur H. (2010) Determination of Cu, Pb, Zn, Ni, $\mathrm{Co}, \mathrm{Cd}$, and $\mathrm{Mn}$ in road dusts of Samsun City. Environmental Monitoring and Assessment 168(1-4): 241-253. doi: 10.1007/s10661-009-1108-1.

[24] Kanwal U, Ali S, Shakoor MB, Farid M, Hussain S, Yasmeen T, Adrees M, Bharwana SA, Abbas F. (2014) EDTA ameliorates phytoextraction of lead and plant growth by reducing morphological and biochemical injuries in Brassica napus L. under lead stress. Environmental Science and Pollution Research, 21(16), 9899-9910.

[25] Khaliq A, Ali S, Hameed A, Farooq MA, Farid M, Shakoor MB, Mahmood K, Ishaque W, Rizwan M (2015) Silicon alleviates nickel toxicity in cotton seedlings through enhancing growth, photosynthesis and suppressing Ni uptake and oxidative stress. Archives of Agronomy and Soil Science 62(5): 633-647. doi: 10.1080/03650340.2015.1073263.

[26] Kim ND, Fergusson JE (1994) The concentrations, distribution and sources of cadmium, copper, lead and zinc in the atmosphere of an urban environment. Science of The Total Environment 144(1-3): 179-189. doi: 10.1016/00489697(94)90437-5

[27] Léonard A, Lauwerys RR (1980) Carcinogenicity and mutagenicity of chromium. Mutation Research/Reviews in Genetic Toxicology 76(3): 227-239. doi: 10.1016/01651110(80)90018-4.

[28] Li X, Poon CS, Liu PS (2001) Heavy metal contamination of urban soils and street dusts in Hong Kong. Applied Geochemistry 16(11-12): 1361-1368. doi: 10.1016/S08832927(01)00045-2.

[29] Lindsay WL, Norvell WA (1978) Development of a DTPA soil test for zinc, iron, manganese, and copper. Soil science society of America Journal,42(3), 421-428. doi: 10.2136/sssaj 1978.03615995004200030009x.

[30] Liu R, Guan CQ (2005) Mode biases of urban transportation policies in China and their implications. Journal of Urban Planning and Development. 131(2): 58-70. doi: 10.1061/(ASCE)0733-9488(2005)131: 2(58).

[31] Lokeshwari H, Chandrappa GT (2006) Impact of heavy metal contamination of Bellandur Lake on soil and cultivated vegetation. Current Science 91(5): 622-627. 
[32] Muchuweti M, Birkett JW, Chinyanga E, Zvauya R, Scrimshaw MD, Lester JN (2006) Heavy metal content of vegetables irrigated with mixtures of wastewater and sewage sludge in Zimbabwe: Implications for human health. Agriculture, Ecosystems \& Environment 112(1): 41-48. doi: 10.1016/j.agee.2005.04.028.

[33] Rahman SH, Khanam D, Adyel TM, Islam MS, Ahsan MA, Akbor MA (2012) Assessment of heavy metal contamination of agricultural soil around Dhaka Export Processing Zone (DEPZ), Bangladesh: Implication of seasonal variation and indices. Applied Sciences 2(3): 584-601. doi: 10.3390/app2030584.

[34] Rizo OD, Castillo FE, López JA, Merlo MH (2011) Assessment of heavy metal pollution in urban soils of Havana city, Cuba. Bulletin of Environmental Contamination and Toxicology 87(4): 414-419. doi: 10.1007/s00128-011-0378-9.

[35] Rizwan M, Ali S, Ibrahim M, Farid M, Adrees M, Bharwana SA, Zia-ur-Rehman M, Qayyum MF, Abbas F (2015) Mechanisms of silicon-mediated alleviation of drought and salt stress in plants: a review. Environmental Science and Pollution Research 22(20): 15416-15431. doi: 10.1007/s11356-015-5305-x.

[36] Shakoor MB, Ali S, Farid M, Farooq MA, Tauqeer HM, Iftikhar U, Hannan F, Bharwana SA (2013) Heavy metal pollution, a global problem and its remediation by chemically enhanced phytoremediation: A review. Journal of Biodiversity and Environmental Sciences 3(3): 12-20.

[37] Shakoor MB, Ali S, Hameed A, Farid M, Hussain S, Yasmeen T, Najeeb U, Bharwana SA, Abbasi GH (2014) Citric acid improves lead $(\mathrm{Pb})$ phytoextraction in Brassica napus $\mathrm{L}$. by mitigating $\mathrm{Pb}$-induced morphological and biochemical damages. Ecotoxicology and Environmental Safety. 109: 38-47.

[38] Shapiro RJ, Hassett KA, Arnold FS (2002) Conserving energy and preserving the environment: The role of public transportation. Report by American Public Transportation Association. 39p. Available at: https://www.apta.com/resources/reportsandpublications/Docu ments/shapiro.pdf [access date: 09.08.2016].

[39] Sharma RK, Agrawal M, Marshall FM (2008) Heavy metal $(\mathrm{Cu}, \mathrm{Zn}, \mathrm{Cd}$ and $\mathrm{Pb})$ contamination of vegetables in urban India: A case study in Varanasi. Environmental Pollution 154(2): 254-263. doi: 10.1016/j.envpol.2007.10.010.

[40] Victoria A, Cobbina SJ, Dampare SB, Duwiejuah AB (2014) Heavy Metals Concentration in Road Dust in the Bolgatanga Municipality, Ghana. Journal of Environment Pollution and Human Health 2(4): 74-80. doi: 10.12691/jephh-2-4-1.

[41] Walters GI, Moore VC, Robertson AS, Burge CBSG, Vellore AD, Burge PS (2012) An outbreak of occupational asthma due to chromium and cobalt. Occupational Medicine 62(7): 533540. doi: 10.1093/occmed/kqs111.

[42] Worldmeters (2016) Population of Pakistan, Retrieved 27 August 2016, from http://www.worldometers.info/worldpopulation/pakistan-population/.

[43] Wei B, Jiang F, Li X, Mu S (2010) Contamination levels assessment of potential toxic metals in road dust deposited in different types of urban environment. Environmental Earth Sciences 61(6): 1187-1196. doi:: 10.1007/s12665-009-0441-6.

[44] Yan X, Gao D, Zhang F, Zeng C, Xiang W, Zhang M (2013) Relationships between heavy metal concentrations in roadside topsoil and distance to road edge based on field sources observations in the Qinghai-Tibet Plateau, China. International Journal of Environmental Research and Public Health 10(3): 762-775. doi: 10.3390/ijerph10030762.

[45] Yang Z, Lu W, Long Y, Bao X, Yang Q (2011) Assessment of heavy metals contamination in urban topsoil from Changchun City, China. Journal of Geochemical Exploration 108(1): 2738. doi: 10.1016/j.gexplo.2010.09.006. 